\title{
A One-pot Multicomponent Reaction for the Synthesis of Oligoetherols with Azacyclic Rings
}

\author{
Jacek Lubczak, Renata Lubczak and Iwona Zarzyka \\ Rzeszów University of Technology, Department of Organic Chemistry, Al. Powstańców Warszawy 6, \\ 35-959 Rzeszów, Poland \\ *Corresponding author: E-mail: jml@prz.edu.pl
}

Received: 04-05-2017

\begin{abstract}
The one-pot multicomponent synthesis of oligoetherols containing azacycles is described. They were obtained by reaction of isocyanuric, barbituric, or uric acid or melamine with glycidol and alkylene carbonates. The isolated products were characterized by physical methods and their properties were compared with the same compounds obtained in twostep protocol. The oligoetherols with 1,3,5-triazine ring obtained by both methods were then used to form polyurethane foams and their properties were compared.
\end{abstract}

Keywords: Azacyclic compounds, glycidol, alkylene carbonates, oligoetherols, one-pot multicomponent reactions, polyurethane foams

\section{Introduction}

The methods of obtaining oligoetherols with azacycles like perhydro-1,3,5-triazine, 1,3,5-triazine, purine or pyrimidine rings, which are present in the structure of isocyanuric acid (IA, I), uric acid (UA, II), barbituric acid (BA, III), and melamine (MEL, IV) (Scheme 1) are described in the literature. ${ }^{1,2}$

These oligoetherols can be applied to form rigid polyurethane foams (PUFs) of enhanced thermal resistance due to the presence of above mentioned rings. Oligoetherols can be obtained from IA, MEL or adenine and excess oxiranes like ethylene oxide (EO) or propylene oxide $(\mathrm{PO})^{3-5}$ or from the reaction of alkylene carbonates (AC) with the mentioned azacylic compounds. ${ }^{2}$ General reaction pathway is shown in Scheme 2.<smiles>O=c1[nH]c(=O)[nH]c(=O)[nH]1</smiles>

(I)<smiles>O=c1[nH][nH]c2c(=O)[nH]c(=O)c=2[nH]1</smiles>

(II)

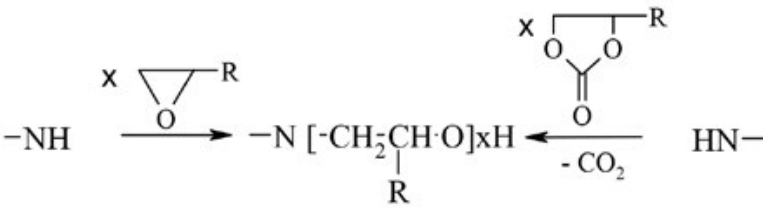

Scheme 2. Reaction NH groups with oxiranes or alkylene carbonates

where $\mathrm{R}=-\mathrm{H}, \mathrm{CH}_{3}$

The non-catalytic reactions of IA, UA, BA and MEL with glycidol (GL), ${ }^{6}$ and later with $\mathrm{AC}^{7-9}$ also led to the mentioned oligoetherols. Those syntheses were conducted in two steps; in the first step hydroxyalkyl derivatives of azacycles were obtained as semi-solid resins in reaction of<smiles>Nc1nc(N)nc(N)n1</smiles>

(III) (IV)

Scheme 1. Azacyclic compounds used to obtain oligoetherols 
azacycles with GL, and then the semiproducts were hydroxyalkylated with excess of ethylene (EC) or propylene (PC) carbonates in the presence of potassium carbonate catalyst according to the Scheme 3.
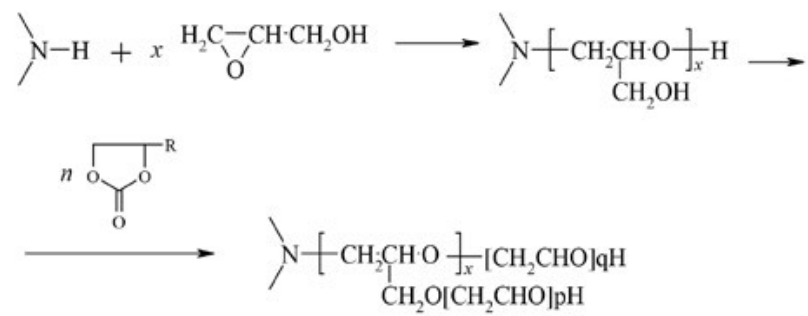

Scheme 3. Obtaining of oligoetherols in two steps: reaction $\mathrm{NH}$ groups in azacycles compounds with glycidol and then with alkylene carbonates

where $\mathrm{R}=-\mathrm{H}, \mathrm{CH}_{3}, \quad p+q=n$

Those methods have some disadvantages. The derivatization of azacycles with oxiranes is difficult due to low solubility of azacycles in organic solvents suitable for synthesis. Moreover, high boiling solvents like dimethylsulfoxide (DMSO) have to be vaccum distilled from post-reaction mixtures. The DMSO is also unstable at elevated temperatures and its odor originates from the products of its decomposition. ${ }^{2}$ On the other hand, the oxiranes are low boiling reagents, therefore the pressure reactors must be used. Also, the oxiranes are toxic, cancerogenic, and form explosive mixtures with air. ${ }^{10}$ When $\mathrm{AC}$ are used instead oxiranes, the structures of the products are very similar. The reactions with excess $\mathrm{AC}$ can be performed at temperatures between $160^{\circ} \mathrm{C}$ and $200{ }^{\circ} \mathrm{C}$ in the presence of catalysts, like potassium carbonate or diaza[2.2.2]bicyclooctane (DABCO). This protocol results in formation of products with limited functionality and partial decomposition of oligoetherols at synthesis temperature, especially the dehydration of products resulting in the formation of double $\mathrm{C}=\mathrm{C}$ bonds. That side-reaction also diminishes the functionality of products and finally the PUFs obtained from them have diminished mechanical properties.

Considering the two step synthesis by reaction of azacycle with GL, followed by AC, the exothermic effect observed during the first step causes the temperature increase even above $200{ }^{\circ} \mathrm{C}$ (Table 1) which may result in thermal decomposition of oligoetherols. Therefore, the scale-up of this process is technically demanding. Furthermore, the obtained products are semi-solid resins; the high viscosity of the oligoetherols very difficult proper homogenization with isocyanates. Therefore the application of $\mathrm{AC}$ for further hydroxyalkylation is necessary to obtain a product of lower viscosity.

Here we describe the results on multicomponent reaction and one-pot reaction (multicomponent one-pot reaction, MOPR) which were optimized in a way to eliminate above mentioned disadvantages. Thus we have ob- tained one product from at least three substrates introduced at the beginning of the process. In MOPR method the reagents were added consecutively, after the previous step was completed. The products obtained by both methods were isolated and purified in the same way and their properties were compared to those of the products obtained in the two-step protocol. The oligoetherols obtained from MEL were also tested as substrates for polyurethane foams (PUFs). The PUFs obtained here were also compared to those PUFs which were obtained from the oligoetherols synthesized in two-step protocol.

\section{Experimental Section}

\section{1. Synthesis}

To a three-neck round bottom flask equipped with mechanical stirrer, reflux condenser, and thermometer the following reagents were introduced:

- 0.6 mol EC (pure, Fluka, Schwitzeland) or PC (pure, Fluka, Schwitzeland), $0.6 \mathrm{~mol} \mathrm{GL}$ (pure, Sigma-Aldrich, Germany), and $0.1 \mathrm{~mol}$ IA (pure, Flu$\mathrm{ka}$, Switzerland) or

- $0.7 \mathrm{~mol} \mathrm{EC}$ or PC, $0.6 \mathrm{~mol} \mathrm{GL}$, and $0.1 \mathrm{~mol} \mathrm{UA}$ (pure, Avocado, Germany) or

- $0.8 \mathrm{~mol} \mathrm{EC}$ or PC, $0.4 \mathrm{~mol} \mathrm{GL}$, and $0.1 \mathrm{~mol} \mathrm{BA}$ (pure, BDH, Laboratory Supplies, UK) or

- $1.6 \mathrm{~mol} \mathrm{EC}$ or $1.2 \mathrm{~mole}$ PC, $0.8 \mathrm{~mol} \mathrm{GL}$ and $0.1 \mathrm{~mol}$ MEL (pure, Fluka, Switzerland).

The mixture was heated at $150{ }^{\circ} \mathrm{C}$ until azacyclic compound was dissolved and afterwards the system was kept as such for 1 hour. In the case the system containing MEL the temperature was raised to $120^{\circ} \mathrm{C}$; at that moment the exothermic effect resulted in increase of temperature to $160^{\circ} \mathrm{C}$. The reaction mixture was cooled down to maintain $150{ }^{\circ} \mathrm{C}$ until dissolution of MEL was completed and further for 1 hour longer. Then the potassium carbonate (pure, $\mathrm{POCH}$, Poland) as catalyst for the reaction with $\mathrm{AC}$ was introduced. The amount of catalyst was the same as previously used for the two-step method; ${ }^{6-9}$ the reactions were performed with IA, BA and UA or MEL and EC at $150^{\circ} \mathrm{C}$ or with $\mathrm{PC}$ at $160^{\circ} \mathrm{C}$ until the completed reaction of AC. The progress of reaction was monitored by epoxide number and concentration of AC.

\section{2. Analytical Methods}

The course of the reaction between azacyclic compounds and GL was followed by measuring the content of epoxide groups. ${ }^{11}$ The progress of reaction between semi-product and AC was monitored using barium hydroxide method described in the literature. ${ }^{12}$ The sample was then treated with $2.5 \mathrm{~mL}$ of $0.15 \mathrm{M}$ barium hydroxide, vigorously shaken and the excess of barium hydroxide titrated off with $0.1 \mathrm{M} \mathrm{HCl}$ solution. Hydroxyl number of 
the obtained oligoetherols was determined with the use of acetic anhydride. ${ }^{13}$ Elemental analysis for $\mathrm{C}, \mathrm{H}, \mathrm{N}$, were done with EA 1108, Carlo-Erba analyzer. IR spectra were registered on PARAGON 1000 FT IR Perkin Elmer spectrometer using ATR technique.

\section{3. Properties of Oligoetherols}

Density, viscosity, and surface tension of oligoetherols were determined with pycnometer, Höppler viscometer (typ BHZ, prod. Prüfgeratewerk, Germany) and by the detaching ring method, respectively. ${ }^{14,15}$

\section{4. Foam Preparation}

Into a $500 \mathrm{~mL}$ cup $10 \mathrm{~g}$ oligoeterol, then $2 \%$ water, 2.3\% silicon L-6900 (pure, Houdry Hülls, USA) as surfactant, and $2.2 \%$ or $3.9 \%$ triethylamine (TEA, pure, $\mathrm{POCH}$, Poland) as catalyst were introduced. The mixture was vigorously stirred and then the polymeric methylene diphenyl 4,4'-diisocyanate (pMDI containing 30 mass\% of three-functional isocyanates, Merck, Darmstadt, Germany) was added. The mixture was vigorously stirred (1800 rpm) until creaming started.

\section{5. Studies of Foams}

The apparent density ${ }^{16}$ water uptake, ${ }^{17}$ dimensional stability in temperature $150{ }^{\circ} \mathrm{C}^{18}$ heat conductance coefficient, heat capacity, and compressive strength ${ }^{19}$ of polyurethanes foams with flame retardants were measured. Thermal resistance of modified foams was determined both by static methods. In static method the foams were heated at 150, 175 and $200{ }^{\circ} \mathrm{C}$ with continuous measurement of mass loss and determination of mechanical properties before and after heat exposure.

\section{Results and Discussion}

\section{1. Synthesis of Oligoetherols}

The synthesis of oligoetherols was performed as stepwise process in the mixture of all necessary reagents, i.e. azacycle, $\mathrm{Gl}$, and AC. This can be considered as multicomponents reaction. The first observed reaction was between azacycle and GL. The second step (the reaction with $\mathrm{AC}$ ) needed addition of catalyst to the reaction mixture. Therefore, the process can also be considered as a one-pot
Table 1. Exothermic effects accompanying the reaction of azacycles with GL in two-steps synthesis of oligoetherols (the starting amount of azacycle was 0.05 mole $)^{6-9}$

\begin{tabular}{lccc}
\hline Oligoetherol & $\begin{array}{c}\text { Reagents } \\
\text { molar ratio }\end{array}$ & $\begin{array}{c}\text { accompanied } \\
\text { exothermic effect } \\
\text { temp. }\left[{ }^{\circ} \mathbf{C}\right]\end{array}$ & $\begin{array}{c}\text { Reaction } \\
\text { time [h] }\end{array}$ \\
\hline IA:GL:EC & $1: 6: 6$ & 150 & 1,5 \\
IA:GL:PC & $1: 6: 6$ & 150 & 1,5 \\
UA: GL:EC & $1: 6: 7$ & 180 & 0.5 \\
UA: GL:PC & $1: 6: 7$ & 180 & 0.5 \\
BA:GL:EC & $1: 4: 8$ & 130 & 3.0 \\
BA:GL:PC & $1: 4: 7$ & 130 & 3.0 \\
MEL:GL:EC & $1: 8: 16$ & 230 & 0.5 \\
MEL:GL:PC & $1: 8: 12$ & 220 & 0.5 \\
\hline
\end{tabular}

reaction. After heating the reaction mixture up to $150{ }^{\circ} \mathrm{C}$ the reaction between azacycle and GL took place. At this stage the AC played the role of a solvent. No exothermic effect was observed in contrary to the two-step method, where after heating of azacycle and GL to $120-130{ }^{\circ} \mathrm{C}$ it was found (Table 1). In the case of MEL as azacycle the exothermic effect was observed at $120^{\circ} \mathrm{C}$ leading to an increase of temperature to $160{ }^{\circ} \mathrm{C}$ (MEL:GL:AC $=1: 8: 8$ system). The temperature of this system was kept at $150^{\circ} \mathrm{C}$ by cooling.

The AC are non-flammable, non-toxic, and very polar ${ }^{10}$ and they are good solvents for azacycles, therefore in the reaction mixture they are useful as solvents, which are not necessary to be removed after completion of the reaction with GL. They react further after introducing the catalyst (potassium carbonate) at $150{ }^{\circ} \mathrm{C}$ or $160{ }^{\circ} \mathrm{C}$ to give oligoetherols. On the other hand, the GL enables to obtain oligoetherols with higher functionality in relations to azacycle. The increase of functionality allows to obtain highly crosslinked, rigid PUFs. Moreover, the hydroxyalkyl derivatives obtained from azacycle and GL are better soluble in AC than azacycles, thus homogenization of the mixtures with $\mathrm{AC}$ can be reached at lower temperatures than in the case of the azacycle-AC system (temperature needed is $180-230^{\circ} \mathrm{C}$ ). This allows to avoid thermal decomposition of the semiproducts.

We have obtained oligoetherols in the reaction of azacycles with GL and AC at the same molar ratio of substrates as it has been used earlier in the two-step protocols..$^{6-9}$ Analysis of the products obtained from IA, UA, or $\mathrm{BA}$ with GL and AC indicated that amount of $\mathrm{AC}$ in the

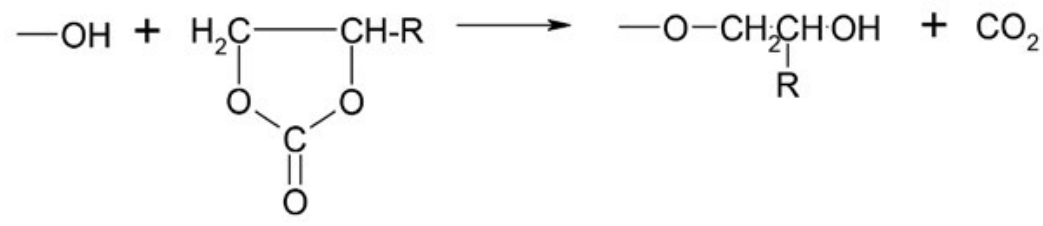

Scheme 4. Reaction of alkylene carbonate with hydroxyl group 
reaction mixture did not change upon reaction of azacycle with GL, while in the case of MEL, the AC was also consumed at the level of up to $5 \%$ of the initial amount. Then, in the latter system, MEL is hydroxylated also with AC. Generally AC releases $\mathrm{CO}_{2}$ during the condensation with hydroxyl groups, according to the Scheme 4.

Table 2. Elemental analysis and hydroxyl number of oligoetherols obtained in MOPR and two-steps reactions ${ }^{6-9}$

\begin{tabular}{|c|c|c|c|c|c|c|c|c|c|c|}
\hline \multirow[t]{2}{*}{ Oligoetherol } & \multirow{2}{*}{$\begin{array}{l}\text { Reagents } \\
\text { molar } \\
\text { ratio }\end{array}$} & \multirow{2}{*}{$\begin{array}{l}\text { Method } \\
\text { of synthesis } \\
\text { of oligo- } \\
\text { etherol }\end{array}$} & \multicolumn{6}{|c|}{$\begin{array}{l}\text { Elemental analysis [\% mas] } \\
\text { ulated }\end{array}$} & \multicolumn{2}{|c|}{$\begin{array}{c}\text { Hydroxyl } \\
\text { number } \\
{[\mathrm{mgKOH} / \mathrm{g}]}\end{array}$} \\
\hline & & & $\mathrm{C}$ & $\mathbf{H}$ & $\mathbf{N}$ & C & $\mathbf{H}$ & $\mathbf{N}$ & found & calc. \\
\hline IA:GL:EC & $1: 6: 6$ & $\begin{array}{l}\text { MOPR } \\
\text { two-step }\end{array}$ & 47.31 & 7.53 & 5.02 & $\begin{array}{l}47.21 \\
47.51\end{array}$ & $\begin{array}{l}7.72 \\
7.24\end{array}$ & $\begin{array}{l}4.95 \\
5.04\end{array}$ & $5 \underline{9} 2$ & 603 \\
\hline IA:GL:PC & $1: 6: 6$ & $\begin{array}{l}\text { MOPR } \\
\text { two-step }\end{array}$ & 50.81 & 8.14 & 4.56 & $\begin{array}{l}50.88 \\
50.69\end{array}$ & $\begin{array}{l}8.25 \\
8.44\end{array}$ & $\begin{array}{l}4.48 \\
4.84\end{array}$ & $5 \underline{3} 4$ & 548 \\
\hline UA: GL:EC & $1: 6: 7$ & $\begin{array}{l}\text { MOPR } \\
\text { two-step }^{8}\end{array}$ & 48.26 & 7.39 & 6.09 & $\begin{array}{l}48.13 \\
48.51\end{array}$ & $\begin{array}{l}7.12 \\
7.03\end{array}$ & $\begin{array}{l}6.25 \\
6.21\end{array}$ & $\begin{array}{l}571 \\
595\end{array}$ & 610 \\
\hline UA: GL:PC & $\begin{array}{l}1: 6: 7 \\
1: 6: 8\end{array}$ & $\begin{array}{l}\text { MOPR } \\
\text { two-step }\end{array}$ & $\begin{array}{l}51.87 \\
52.42\end{array}$ & $\begin{array}{l}8.06 \\
8.18\end{array}$ & $\begin{array}{l}5.50 \\
5.20\end{array}$ & $\begin{array}{l}52.52 \\
51.95\end{array}$ & $\begin{array}{l}8.25 \\
8.40\end{array}$ & $\begin{array}{l}5.38 \\
5.83\end{array}$ & $\begin{array}{l}504 \\
525\end{array}$ & $\begin{array}{l}551 \\
521\end{array}$ \\
\hline BA:GL:EC & $1: 4: 8$ & $\begin{array}{c}\text { MOPR } \\
\text { two-step }\end{array}$ & 49.48 & 7.73 & 3.60 & 49.79 & 8.03 & 3.58 & $\begin{array}{l}560 \\
558\end{array}$ & 578 \\
\hline BA:GL:PC & $1: 4: 7$ & $\begin{array}{l}\text { MOPR } \\
\text { two-step }\end{array}$ & 53.49 & 8.43 & 3.37 & 53.41 & 8.46 & 3.51 & $\begin{array}{l}535 \\
527\end{array}$ & 540 \\
\hline MEL:GL:EC & $1: 8: 16$ & $\begin{array}{c}\text { MOPR } \\
\text { two-step }^{6}\end{array}$ & 49.79 & 8.30 & 5.90 & $\begin{array}{l}50.07 \\
49.60\end{array}$ & $\begin{array}{l}8.21 \\
8.43\end{array}$ & $\begin{array}{l}5.53 \\
5.44\end{array}$ & $\begin{array}{l}517 \\
544\end{array}$ & 552 \\
\hline MEL:GL:PC & $1: 8: 12$ & $\begin{array}{c}\text { MOPR } \\
\text { two-step }\end{array}$ & 53.46 & 8.91 & 5.94 & $\begin{array}{l}53.87 \\
53.02\end{array}$ & $\begin{array}{l}8.81 \\
8.75\end{array}$ & $\begin{array}{l}6.23 \\
5.70\end{array}$ & $\begin{array}{l}525 \\
548\end{array}$ & 476 \\
\hline
\end{tabular}

Table 3. The physical properties of oligoetherols at $20{ }^{\circ} \mathrm{C}$ obtained various methods in the reaction of azacycles with GL and AC

\begin{tabular}{|c|c|c|c|c|c|}
\hline Oligoetherol & $\begin{array}{l}\text { Reagents } \\
\text { molar } \\
\text { ratio }\end{array}$ & $\begin{array}{c}\text { Method } \\
\text { of synthesis } \\
\text { of oligo-etherol }\end{array}$ & $\begin{array}{l}\text { Density } \\
{\left[\mathrm{g} / \mathrm{cm}^{3}\right]}\end{array}$ & $\begin{array}{l}\text { Viscosity } \\
{[\mathrm{mPa} \times \mathrm{s}]}\end{array}$ & $\begin{array}{l}\text { Surface tension } \\
{[\mathrm{N} / \mathrm{m}] \times 10^{3}}\end{array}$ \\
\hline \multirow{2}{*}{ IA:GL:EC } & \multirow{2}{*}{$1: 6: 6$} & MOPR & 1.28 & 17200 & 50.8 \\
\hline & & two-step ${ }^{7}$ & 1.28 & 17220 & 52.6 \\
\hline \multirow{2}{*}{ IA:GL:PC } & \multirow{2}{*}{$1: 6: 6$} & MOPR & 1.24 & 16920 & 48.2 \\
\hline & & two-step ${ }^{7}$ & 1.20 & 16970 & 46.9 \\
\hline \multirow{2}{*}{ UA:GL:EC } & \multirow{2}{*}{$1: 6: 7$} & MOPR & 1.27 & $30200\left(30^{\circ} \mathrm{C}\right)$ & 52.4 \\
\hline & & two-step ${ }^{8}$ & 1.28 & $35000\left(30^{\circ} \mathrm{C}\right)$ & 57.0 \\
\hline \multirow{2}{*}{ UA:GL:PC } & \multirow{2}{*}{ 1:6:7 (8) } & MOPR & 1.21 & 42800 & 45.2 \\
\hline & & two-step ${ }^{8}$ & 1.21 & 47500 & 47.0 \\
\hline \multirow{2}{*}{ BA:GL:EC } & \multirow{2}{*}{$1: 4: 8$} & MOPR & 1.26 & 93.2 & 45.8 \\
\hline & & two-step ${ }^{9}$ & 1.26 & 95.6 & 46.5 \\
\hline \multirow{2}{*}{ BA:GL:PC } & \multirow{2}{*}{$1: 4: 7$} & MOPR & 1.17 & 86.8 & 46.8 \\
\hline & & two-step ${ }^{9}$ & 1.18 & 86.3 & 46.5 \\
\hline \multirow{2}{*}{ MEL:GL:EC } & \multirow{2}{*}{$1: 8: 16$} & MOPR & 1.28 & 8445 & 54.2 \\
\hline & & two-step ${ }^{6}$ & 1.26 & 34260 & 46.2 \\
\hline \multirow{2}{*}{ MEL:GL:PC } & \multirow{2}{*}{$1: 8: 12$} & MOPR & 1.20 & 25640 & 46.3 \\
\hline & & two-step ${ }^{6}$ & 1.19 & 65430 & 43.5 \\
\hline
\end{tabular}


Elemental analytical data and hydroxyl number measurements indicated that the composition of the obtained oligoetherols is comparable with those of oligoetherols obtained from the two-step reactions (Table 2). Exceptionally the oligoetherol obtained from UA:GL:PC = 1:6:8 system has one equivalent of PC-derived oxyalkylene group more than the oligoetherol obtained in the two-step process. This difference is due to the higher temperature of reaction applied in the two-step protocol, which caused partial decomposition of PC to PO and $\mathrm{CO}_{2}$ volatiles.

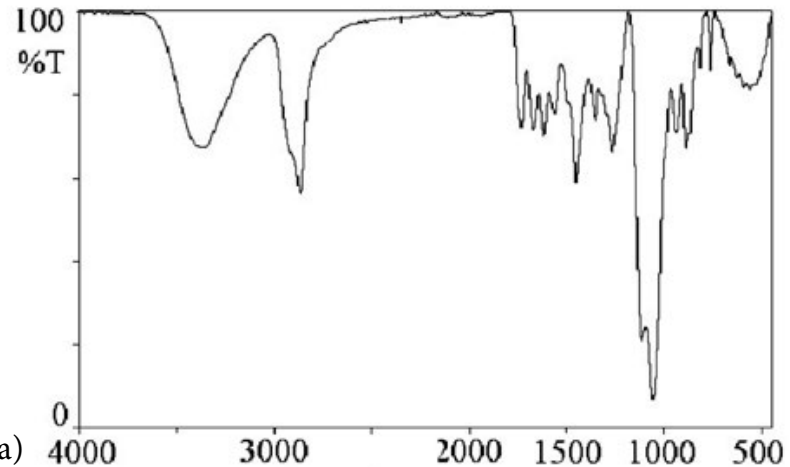

b)

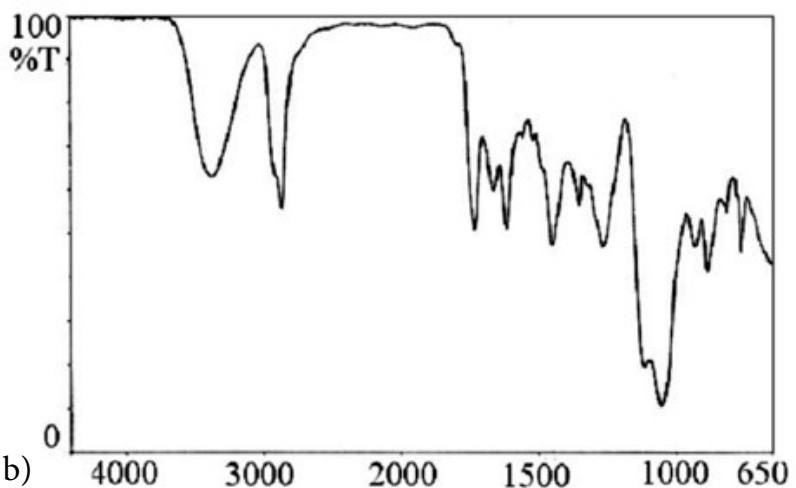

Fig. 1. IR spectrum of oligoetherols obtained in MOPR (a) and in the two-step reaction (b) in molar ratio MEL:GL:EC $=1: 8: 16$
The density, viscosity, surface tension and hydroxyl number of oligoetherols obtained from azacycles, GL, and AC with MOPR method and two-steps method ${ }^{6-9}$ are collected in Table 3. The parameters of both series of oligoetherols are comparable except the oligoetherols obtained from MEL. Generally, the oligoetherols obtained in the two-step protocol had higher viscosity, which can be explained by condensation of hydroxyalkyl groups at high temperature and longer reaction time than in the MOPR method.

The IR spectra of oligoetherols obtained from MEL in MOPR method are similar to those obtained in the twosteps method (Fig. 1a versus 1b). In both cases the broad valence hydroxyl group band is centered at $3324 \mathrm{~cm}^{-1}$. The ring $\mathrm{C}=\mathrm{N}$ valence band was observed within $1660-1470$ $\mathrm{cm}^{-1}$ region, while $\mathrm{C}-\mathrm{OH}$ vibrations were found in the $1350-1450 \mathrm{~cm}^{-1}$ region. The product of the reaction between MEL and GL and EC had a characteristic band at $2870 \mathrm{~cm}^{-1}$ attributed to the methylene and methine groups. The band at $813 \mathrm{~cm}^{-1}$ was related to the 1,3,5-triazine ring, while ether bonds led to the appearance of the band at $1055 \mathrm{~cm}^{-1}$. The spectra of the products obtained from PC instead of EC are similar; the additional low-intensity band at $1372 \mathrm{~cm}^{-1}$ was attributed to the deformation vibration of methyl group. IR spectra of oligoetherols obtained from IA, BA and UA using MOPR and the two-stage method are very similar.

\section{2. Obtaining of Polyurethane Foams}

The substantial difference of physical properties of the oligoetherols obtained from MEL in MOPR method in comparison with the analogues obtained in the two-steps synthesis prompted us to further study these compounds as substrates to form PUFs. It has been found that amount of isocyanate necessary to form the PUF is independent of the method used (Table 4). However, the optimized amount of catalyst and surfactants are lower in the syntheses by MOPR protocol. Cream times were similar, while rise times are longer and drying times are shorter, which

Table 4. Foaming process

\begin{tabular}{|c|c|c|c|c|c|c|c|}
\hline \multirow{2}{*}{ Oligoetherol } & \multirow{2}{*}{$\begin{array}{c}\text { Method } \\
\text { of synthesis } \\
\text { of oligo-etherol }\end{array}$} & \multicolumn{3}{|c|}{$\begin{array}{l}\text { Amount of co-substrate } \\
\text { [g/100g oligoetherol] }\end{array}$} & \multicolumn{3}{|c|}{ Foaming Process } \\
\hline & & pMDI & TEA & silicone & $\begin{array}{l}\text { Cream } \\
\text { time }[s]\end{array}$ & $\begin{array}{c}\text { Rise } \\
\text { time }[s]\end{array}$ & $\begin{array}{l}\text { Tack free } \\
\text { time }[s]\end{array}$ \\
\hline MEL:GL:EC & MOPR & 160 & 2.2 & 2.3 & 20 & 30 & immediately \\
\hline $1: 8: 16$ & two-step ${ }^{6}$ & 160 & 3.9 & 3.2 & 22 & 13 & 35 \\
\hline MEL:GL:PC & MOPR & 152 & 3.9 & 2.3 & 24 & 24 & immediately \\
\hline $1: 8: 12$ & two-step ${ }^{6}$ & 152 & 6.2 & 3.2 & 24 & 11 & 24 \\
\hline
\end{tabular}

2 mass \% of water related to the mass of oligoetherol was used in both methods

Cream time: the time elapsed from the moment of mixing to the start of volume expansion;

Rise time: the time from the start of expansion to the moment of reaching the sample final volume;

Tack free time: the time from reaching by the sample its final volume to the moment of losing its surface adhesion 
Table 5. Some properties of polyurethane foams

\begin{tabular}{|c|c|c|c|c|c|c|c|c|c|c|c|c|}
\hline \multirow{3}{*}{$\begin{array}{l}\text { Foam } \\
\text { obtained } \\
\text { from } \\
\text { oligoetherol }\end{array}$} & \multirow{3}{*}{$\begin{array}{l}\text { Method of } \\
\text { synthesis } \\
\text { of oligo- } \\
\text { etherol }\end{array}$} & \multirow{3}{*}{$\begin{array}{l}\text { Density } \\
{\left[\mathbf{k g} / \mathrm{m}^{3}\right]}\end{array}$} & \multicolumn{9}{|c|}{$\begin{array}{c}\text { Dimensional stability [\%] } \\
\text { in temperature } 150^{\circ} \mathrm{C}\end{array}$} & \multirow{3}{*}{$\begin{array}{c}\text { Heat } \\
\text { conductance } \\
\text { coefficient }\end{array}$} \\
\hline & & & \multicolumn{3}{|c|}{$\begin{array}{l}\text { Absorb. of water } \\
\text { [wt \%] after }\end{array}$} & \multicolumn{2}{|c|}{$\begin{array}{c}\text { Length } \\
\text { change [\%] }\end{array}$} & \multicolumn{2}{|c|}{$\begin{array}{c}\text { Width } \\
\text { change [\%] }\end{array}$} & \multicolumn{2}{|c|}{$\begin{array}{c}\text { Hight } \\
\text { change }[\%]\end{array}$} & \\
\hline & & & $5 \mathrm{~min}$ & $3 \mathrm{~h}$ & $24 \mathrm{~h}$ & $20 \mathrm{~h}$ & $40 \mathrm{~h}$ & $20 \mathrm{~h}$ & $40 \mathrm{~h}$ & $20 \mathrm{~h}$ & $40 \mathrm{~h}$ & \\
\hline MEL:GL:EC & & 63 & 1 & 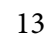 & 1. & -0.44 & -0.59 & -0.69 & -0.74 & -0.46 & -0.48 & $.0322=$ \\
\hline $1: 8: 16$ & two-step $^{6}$ & 67.2 & 4.4 & 6.5 & 8.5 & 0.01 & 0.01 & 0.01 & 0.02 & 0.01 & 0.02 & 0,0667 \\
\hline MEL:GL:PC & MOPR & 42.1 & 1.2 & 1.6 & 1.9 & -0.39 & -0.41 & -0.61 & -0.68 & -0.80 & -0.81 & $0,0344 \pm 0.0006$ \\
\hline $1: 8: 12$ & two-step ${ }^{6}$ & 45.6 & 3.9 & 6.0 & 9.0 & 0.01 & 0.02 & 0.01 & 0.02 & 0.01 & 0.02 & 0.0483 \\
\hline
\end{tabular}

Table 6. Thermal stability and compressive strength of polyurethane foams

\begin{tabular}{|c|c|c|c|c|c|c|c|c|}
\hline \multirow[t]{2}{*}{ Oligoeterol } & \multirow[t]{2}{*}{$\begin{array}{c}\text { Method of synthesis } \\
\text { of oligo- } \\
\text { etherol }\end{array}$} & \multicolumn{3}{|c|}{$\begin{array}{l}\text { Mass loss in \% wt. after } \\
\text { exposure in month } \\
\text { in temperature }\left[{ }^{\circ} \mathrm{C}\right]\end{array}$} & \multirow[t]{2}{*}{ before exposure } & \multicolumn{3}{|c|}{$\begin{array}{c}\text { Compressive strength }[\mathrm{MPa}] \\
\text { after exposure } \\
\text { in temperature }\left[{ }^{\circ} \mathrm{C}\right]\end{array}$} \\
\hline & & 150 & 175 & 200 & & 150 & 175 & 200 \\
\hline \multirow{2}{*}{ MEL:GL:EC } & MOPR & 12.0 & 25.7 & 37.9 & 0.106 & 0.260 & 0.108 & 0.030 \\
\hline & two-step ${ }^{6}$ & 15.0 & 23.9 & 36.8 & 0.134 & 0.208 & 0.245 & 0.229 \\
\hline \multirow{2}{*}{ MEL:GL:PC } & MOPR & 11.8 & 30.0 & 45.6 & 0.152 & 0.404 & 0.316 & 0.034 \\
\hline & two-step ${ }^{6}$ & 13.5 & 23.4 & 35.1 & 0.146 & 0.246 & 0.205 & 0.166 \\
\hline
\end{tabular}

Compression strength measured at $10 \%$ deformation

could be the result of different reactivity of oligoetherols obtained by the MOPR method. The PUFs obtained from oligoetherols synthesized in MOPR are rigid and have similar apparent density as those obtained from the twosteps derived oligoetherols. They have water uptake value $1.9 \%$ in 24 hour test, which is related to domination of closed pores in the structure of PUF (Table 5).

They also showed low polymerization shrinkage. It is noteworthy that generally water uptake of PUFs obtained both from EC and PC in the MOPR is similarly low, while that of PUFs obtained from oligoetherols synthesized in the two-steps method is considerably higher. Also the latter had higher heat conductance coefficient.

The thermal resistance PUFs was studied by static method, i.e. by measuring mass loss within one month heat exposure at 150,175 and $200{ }^{\circ} \mathrm{C}$ with concomitant measurements of compression strength (Table 6). Generally, the PUFs obtained from EC show higher thermal resistance than those obtained from PC (Table 6). For comparison the mass losses of PUFs obtained from MEL, GL, and AC in the two-step method are also collected in the Table 6.

The mass loss of PUFs obtained from oligoetherols synthesized by MOPR with EC involved are comparable with the analogues obtained in the two-step procedure, while mass loss of PUFs obtained by MOPR and PC is considerably larger than that of analogous PUFs obtained from corresponding oligoetherols formed in two-step method. Compression strength of PUFs before thermal exposure does not depend on oligoetherol origin. However, the PUFs obtained from oligoetherols synthesized in
MOPR showed considerable increase of compression strength upon annealing at $150{ }^{\circ} \mathrm{C}$, presumable due to additional crosslinking. However annealing at 175 and $200^{\circ} \mathrm{C}$ resulted in an important decrease of compression strength compared to the PUFs obtained from oligoetherols synthesized in the two-step processes.

\section{Conclusions}

The one-pot multicomponent reaction (MOPR) of synthesis the oligoetherols with azacyclic rings was established. The substrates were azacycles, glycidol, and alkylene carbonates. The oligoetherols obtained by this method showed similar properties as those obtained from the same reagents used consecutively, with isolation of semiproduct, except for oligoetherols obtained from melamine. The oligoetherols obtained in MOPR are useful substrates to obtain polyurethane foams of enhanced thermal resistance.

\section{References}

1. J. Lubczak, Polimery, 2011, 56, 360-368.

2. J. Lubczak, Polimery, 2011, 56, 452-460.

3. K. Frisch, D. Tummers, A. Nijenhuis, Preparation of tris(b-hydroxypropyl)isocyanurate, US Patent Number 4,198,505, date of patent January 18, 1979.

4. T. Śnieżek, E. Andrysiak, W. Montewski, H. Gniadowska, J. 
Wojciechowski, Method of production of branched polyethers, Polish Patent Number 69168, date of patent December 20, 1973.

5. R. Lubczak, J. Appl. Polym. Sci. 2002, 86, 489-497. DOI:10.1002/app.11021

6. K. Cyzio, J. Lubczak, Polymer Int., 2013, 62, 1735-1743. DOI:10.1002/pi.4476

7. K. Cyzio, J. Lubczak, J. Appl. Polym. Sci., 2011, 122, 417-426. DOI:10.1002/app.34131 1

8. K. Cyzio, J. Lubczak, Polym. Plast. Technol. Eng., 2017, 56, 13-21. DOI:10.1080/03602559.2016.1211693

9. E. Kania, J. Lubczak, Polimery, 2014, 59, 851-854. DOI:10.14314/polimery.2014.851

10. D. Kijowska, Przemysł chemiczny, 2005, 84, 678-683.

11. Z. Brojer, P. Penczek, Epoxide resins, WNT, Warsaw, Poland, 1972, pp. 451-452.

12. D. Kijowska, S. Wołowiec, J. Lubczak, J. Appl. Polym Sci., 2004, 93, 294-300. DOI:10.1002/app.20453

13. B. Czupryński, Questions of chemistry and technology of polyurethanes, The Publishing House of the Academy of Bydgoszcz, Poland, 2004, pp.195-196.

14. T. Broniewski, A. Iwasiewicz, J. Kapko, W. Płaczek, Testing and evaluation of properties of plastics, WNT, Warsaw, Poland 1967, pp. 129-357.

15. T. Dryński, Laboratory of Physics, PWN, Warsaw, Poland 1967, pp. 125-132.

16. Cellular Plastics and Rubbers. Determination of apparent (bulk) Density, Polish (European) Standards PN-EN ISO 845-2000, Ed. Polish Committee for Standardization.

17. Cellular Plastics, rigid. Determination of Water Absorption, Polish (European) Standards PN-EN ISO 2896-1986, Ed. Polish Committee for Standardization.

18. Cellular Plastics, rigid. Test of dimensional Stability, Polish (European) Standards PN-EN ISO 2796-1986, Ed. Polish Committee for Standardization.

19. Cellular Plastics, Compression Test for rigid Materials, Polish (European) Standards PN- EN ISO 844-1978, Ed. Polish Committee for Standardization.

\section{Povzetek}

Opisujemo enolončno multikomponentno sintezo oligoeterolov, ki vsebujejo azaciklične sisteme. Pripravili smo jih z reakcijami izocianurne, barbiturne ali sečne kisline oz. melamina z glicidolom in alkil karbonati. Izolirane produkte smo karakterizirali s pomočjo fizikalnih metod in pripravljene spojine primerjali s spojinami, ki smo jih pridobili $\mathrm{z}$ dvostopenjskim protokolom. Oligoeterole z 1,3,5-triazinskim obročem, dobljene $\mathrm{z}$ obema metodama, smo uporabili za pripravo poliuretanskih pen; katerih lastnosti smo tudi primerjali. 